\title{
Sinu-atrial Node of Mature Dromedary Camel Heart (Camelus dromedarius) with special Emphasis on the Atrial Purkinje like Cardiomyocytes
}

Wael Ghonimi ${ }^{1 *}$, Ahmad Balah ${ }^{1}$, Mohamed Hafez Bareedy, Shehata MM Soliman ${ }^{2}$, Ahmad Sharaf ${ }^{1}$, Ahmad Elbaz ${ }^{1}$ and Ahmad Awad Abuel-atta ${ }^{1}$

${ }^{1}$ Department of Histology and Cytology, Faculty of Veterinary Medicine, Zagazig University, Zagazig, Egypt

${ }^{2}$ Department of Histology and Cytology, Faculty of Veterinary Medicine, Minia University, Minia, Egypt

\begin{abstract}
The sinu-atrial node (SAN) is one of the impulse conducting system of the camel heart. Anatomically, it lies beneath the epicardium, at the cranial end of the terminal sulcus, near the junction between the superior vena cava to the lateral wall of the right atrium and the right auricle. Histologically, SAN is located in the subepicardial layer of the terminal crest and can be identified as a mass of specialized and modified cardiac myocytes. Moreover, it appeared elongated in shape and bent oblong. SAN appears strongly similar to the general structure of the glands where, it is formed of two parts; the stroma and the parenchyma. The stroma is consisted of a fibrous connective tissue capsule that is completely investing the SAN from all sides. From the capsule, thin connective tissue septa or trabeculae are extending to inside the node, dividing the later into lobes. These lobes form the SAN head or the SAN body. From this body, the SAN arms processes take their way out. These arms are considered the internodal and interatrial pathways to the different sites in the right and left atria. So, the SAN head with arms giving the octopus likeappearance for the node. The parenchyma is consisted of three different types of specialized and modified cardiac myocytes; the perinuclear clear zone cells ("P" cells), the transitional cells ("T" cells) and the atrial Purkinje like cells or Purkinje like conducting cells.
\end{abstract}

Keywords: SSinus node; Perinuclear clear zone cells; Transitional cells; Atrial Purkinje like cells; Heart; Dromedary camel; SAN

\section{Introduction}

The heart muscles have the capacity to generate the cardiac impulse and then to conduct it from the atrial to the ventricular chambers. This population has become known as the conduction system [1]. The conduction system extends from the sinu-atria node then the AV node to the penetrating atrioventricular bundle and then divides into the left and right bundle branches which descend through the interventricular septum [2].

Getty [3] and Nickel et al. [4] in domestic animals stated that the heart must alternately contract and relax in order to pump and to receive the blood. The alternate contraction and relaxation is an inherent myogenic phenomenon. The heart will contract rhythmically in the embryo before nerves have reached it. However, in postnatal life it is regulated by the autonomic nervous system. Cardiac rhythmicity is due to the conduction system, which consists of the sino-atrial node, the atrioventricular node, the atrioventricular bundle and the terminal conducting or purkinje fibers. The fibers of heart muscle all interconnect with each other, forming a "functional syncytium-like mass." The intrinsic rhythmic contractions are due to the modified cardiac muscle that makes up the conduction system. However, even if the conducting system between the atria and ventricles is destroyed, the ventricles and atria retain an innate power of spontaneous contractibility, but at different rhythms.

The sinu-atrial node is a very small mass of modified heart muscle termed the "pacemaker" for the heart as it has the basic ability to initiate excitation. It is located in the terminal crest at the junction of the cranial vena cava and right auricle. It is embedded without sharp demarcation in the musculature which continues from the atrium onto the cranial vena cava [3].

In goat (Capra hircus), the sinu-atrial node lies $0.18 \mathrm{~mm}-0.25 \mathrm{~mm}$ beneath the epicardium, at terminal sulcus, near the junction between the cranial vena cava, lateral wall of the right atrium and the right auricle. Its shape is elongated and relatively cone shape. Its cranial end is near the myocardium of the right auricle and caudal end is near the myocardium of atrial wall. The caudal end is narrower than the cranial end [5].

The sinu- atrial node is a small mass of specialized cardiac muscle fibers and associated fibro-elastic connective tissue. It lies in the wall of the superior vena cava, close to the site where this borders on the right atrium. The muscle fibers of the SA node are somewhat narrower than the ordinary atrial muscle fibers, and since their role is to initiate and conduct impulses, not to undergo strong contractions, they contain fewer myofibrils. The SA node is supplied with efferent postganglionic fibers from both divisions of the autonomic nervous system, as well as having its own individual blood supply. Each wave of excitation eliciting a heart beat originates as a spontaneous depolarization of cardiac muscle pacemaker cells in the SA node. The frequency of SA nodal depolarization depends on which of the autonomic divisions is supplying efferent impulses. Sympathetic stimulation accelerates the heart rate and increases the force of cardiac contraction. Parasympathetic stimulation lowers the heart rate and decreases the force of cardiac contraction [6].

The sinoatrial node is composed of a network of thin, branching

*Corresponding author: Wael Ghonimi, Department of Histology and Cytology, Faculty of Veterinary Medicine, Zagazig University, Zagazig, Egypt, Tel: 00201222498246; E-mail: drwael_histology@yahoo.com; waghonimi@zu.edu.eg

Received March 14, 2015; Accepted March 28, 2015; Published March 30, 2015.

Citation: Ghonimi W, balah A, bareedy MH, Soliman MMS, Sharaf A, et al. (2015) Sinu-atrial Node of Mature Dromedary Camel Heart (Camelus dromedarius) with special Emphasis on the Atrial Purkinje like Cardiomyocytes. J Cytol Histol 6: 319. doi:10.4172/2157-7099.1000319

Copyright: @ 2015 Ghonimi W, et al. This is an open-access article distributed under the terms of the Creative Commons Attribution License, which permits unrestricted use, distribution, and reproduction in any medium, provided the original author and source are credited. 
nodal muscle cells that contain scarce myofibrils and lack intercalated disks. They are continuous with ordinary cardiac muscle fibers of the atrial myocardium. Nodal muscle fibers are separated by a relatively large amount of highly vascularized connective tissue, containing many autonomic nerve fibers and occasional ganglion cells (vagus nerve) [7].

The sinu-atrial node consists of specialized cardiac muscle fibers that are more slender than the working atrial muscle fibers and contain few myofibrils. The fibers of the node undergo spontaneous rhythmic depolarization of their membrane, generating impulses that travel through the myocardium activating the working muscle cells. The node is enclosed in connective tissue and innervated by both divisions of the autonomic nervous system. The heart beat can be accelerated by nerves of the sympathetic nervous system or slowed by the parasympathetic nerves [8].

The objective of this investigation is to throw more light on the micromorphological structure of the sinu-atrial node in the mature dromedary camel hearts.

\section{Materials and Methods}

Hearts of six apparently healthy mature camels were collected from Zagazig slaughter house in Sharkia province, Egypt for histological studies. For light microscopy; the cranial end of the terminal sulcus, near the junction between the superior vena cava to the lateral wall of the right atrium and the right auricle were cut and immediately fixed in $10 \%$ buffered neutral formalin and Bouin's fluid. The fixed specimens were processed using the usual histological techniques; dehydrated in ascending grades of ethanol series, cleared in benzene and embedded in paraffin. 5-7 $\mu \mathrm{m}$ thick sections were prepared and mounted on glass slides. These are dewaxed in xylene, hydrated in descending grades of ethanol series and stained with Harris's hematoxylin and eosin (H\&E) for routine histological studies, Masson's trichrome (green) stain for demonstration of collagen fibers and muscle cells cytoplasm [9], Jone's methenamine silver stain for demonstration of the reticular fibers $[10,11]$ and PAS (Periodic acid Schiff technique) for detection of neutral muco-polysaccharides [9]. The microphotography were taken using a digital Dsc-W 130 super steadycyper shot camera connected to an Olympus BX 21 light microscope.

\section{Result}

The SAN is one of the impulse conducting system of the heart and also, is considered a small mass of modified cardiac muscle termed the "pacemaker" for the heart as it has the basic ability to initiate and generate excitation.

Anatomically, the sino-atrial node of the camel heart lies beneath the epicardium, at the cranial end of the terminal sulcus, near the junction between the superior vena cava to the lateral wall of the right atrium and the right auricle (Figure 1a and 1b). Histologically, it is located in the subepicardial layer of the terminal crest and can be identified as a mass of specialized and modified myocardial cells. Moreover, it appeared elongated in shape and bent oblong (Figure 2a-2d).

The histological structure of the SAN appears strongly similar to the general structure of the glands as, it is formed of two parts; the stroma and the parenchyma so, SAN is named sinu-atrial gland or sinus gland (Figure 2a). The stroma is consisted of a fibrous connective tissue capsule which is mainly consisted of dense collagenous fibers that is completely investing the SAN from all sides (Figures $2 \mathrm{~b}$ and 3 ). Moreover, some reticular fibers are also present in the capsule beside the collagen fibers (Figure 2c).
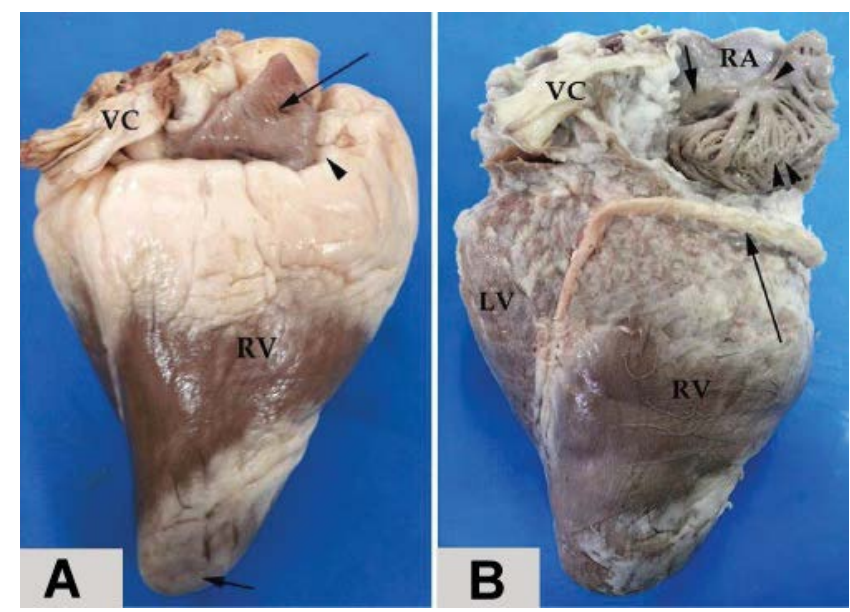

Figure 1: (A) A photograph of the mature camel heart showing the right auricle (long arrow), right atrium (arrow head), Vena cava (VC), the right ventricle (RV) and the Apex of the heart (short arrow). (B) A photograph of the mature camel heart after defattening showing the opened right atrium (RA), the location of SAN (short arrow), Vena cava (VC), terminal crest (single arrow head), the muscle pectinate (double arrow heads) and coronary artery (long arrow), right ventricle (RV), left ventricle (LV).

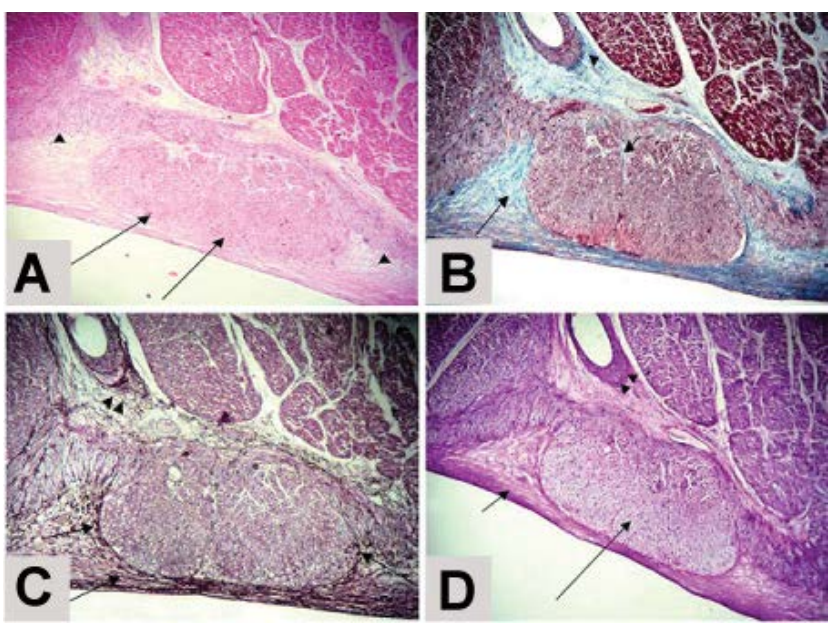

Figure 2: (A) A photomicrograph of the terminal crest epicardium showing the sinu-atrial node head (arrow), and SAN arms (arrow head) Stain: H\& E Obj.x4 : Oc.x10. (B) showing the collagen fibers (arrow), and BV (arrow head) Stain: Green Masson's Trichrome Obj.x4: Oc.x10. (C) showing the reticular fibers (arrow), and BV (arrow head) Stain: Jone's Methenamine Silver stain Obj.x4 : Oc.x10. (D) showing the strongly PAS positive reaction of subepicardium CT. (short arrow), moderately PAS positive reaction of the SAN (long arrow) and BV (arrow head) Stain: PAS Obj.x4 : Oc.x10.

From the capsule, thin connective tissue septa or trabeculae are extending to inside the node, dividing it into lobes. These lobes form the SAN head or the SAN body. From this body, the SAN tails or arms processes take their way out. These arms are considered the internodal and interatrial pathways to the different sites in the right and left atria where through which the initiated impulse from the SAN is conducted. So, the SAN body and tails give the octopus like-appearance (Figures 
Citation: Ghonimi W, Balah A, Bareedy MH, Soliman MMS, Sharaf A, et al. (2015) Sinu-atrial Node of Mature Dromedary Camel Heart (Camelus dromedarius) with special Emphasis on the Atrial Purkinje like Cardiomyocytes. J Cytol Histol 6: 319. doi:10.4172/2157-7099.1000319

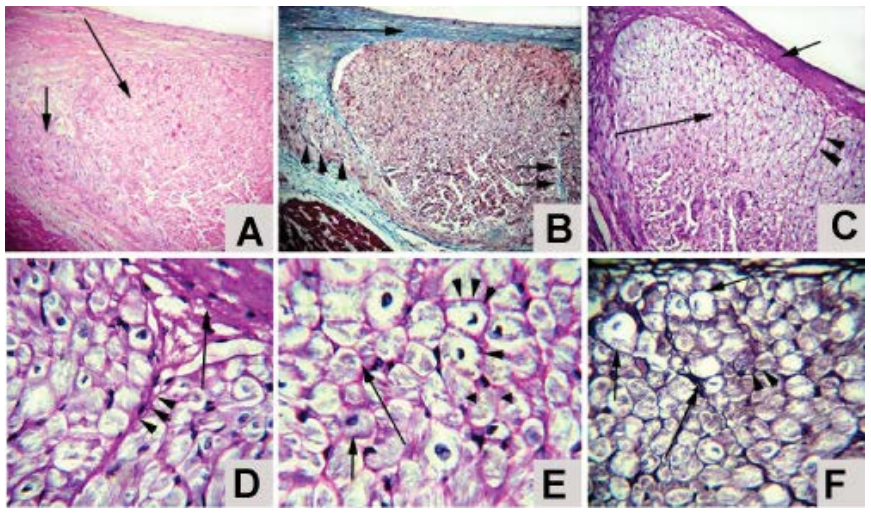

Figure 3: (A): A photomicrograph of the SAN showing one lobe of the SAN head (long arrow), and SAN arm (short arrow) Stain: H\&E Obj.x10 : Oc.x10. (B) showing the SAN capsule (long arrow), the SAN septa (double arrow) and SAN arm (arrow heads) Stain: Green Masson's Trichrome Obj.x10 : Oc.x10. (C) showing the strongly PAS positive reaction of SAN capsule (short arrow), moderately PAS positive reaction of the SAN cells (long arrow) and strongly PAS positive reaction of SAN septa (arrow heads) Stain: PAS Obj.x10 Oc.x10. (D) showing the SAN capsule (long arrow), and SAN septa (arrow heads), (E) showing the inter cellular CT.(long arrow), P. cells (arrow heads) and T. cells (short arrow) Stain: 10, 11) PAS Obj.x40 : Oc.x10. (F) showing the reticular fibers (long arrow), P. cells (short arrow) and T. cells (arrow heads) Stain: Jone's Methenamine Silver stain Obj.x40 : Oc.x10.

2 and $3 c)$.

The CT. capsule and septa of SAN are reacted positively with PAS (Figures 2d and 3c). Meanwhile, the parenchyma of the SAN, is consisted of three different types of specialized and modified cardiac myocytes; the perinuclear clear zone cells ("P" cells), the transitional cells ("T" cells) and the atrial Purkinje like cells or Purkinje like conducting cells (Figures 4a and 4d-4f).

The perinuclear clear zone cells are observed round or ovoid, having a relatively large perinuclear clear zone, with few myofibrils in the cytoplasm and single, central, large nucleus in the cross sections. Moreover, these are appearing smaller in size than working cardiomyocytes, so those are bigger than the transitional cells (Figures $4 \mathrm{a}$ and $4 \mathrm{~d}-4 \mathrm{f})$.

The transitional cells, are also observed round or ovoid but smaller in size than the perinuclear clear zone cells and working cardiac myocytes, without perinuclear clear zone, has more myofibrils than the perinuclear clear zone cells with large, single, central nucleus having distinct nucleoli in the cross sections. Moreover, the two types of cells are weakly reacted to PAS (Figures $4 \mathrm{a}$ and $4 \mathrm{~d}-4 \mathrm{f}$ ).

In the SAN, the "P" cells lied principally within the central portion of the node. The " $T$ " cells were not exclusively at the anatomic margins of the SAN, and they were also visible in varying numbers throughout the node (Figure 4a). These cells are arranged longitudinally into fibers, so making contacts between themselves, but separated from the working cardiomyocytes by dense collagenous fibrous CT capsule (Figure $2 \mathrm{~b}$ and $3 \mathrm{~b}$ ). These cells have less myofibrils than the working cardiac myocytes, therefore, they are appearing paler than the working cardiac myocytes (Figure 2a and 2b). Moreover, these two types of cells are considered the principle cells of the node parenchyma.

Beside the perinuclear clear zone cells ("P" cells) and transitional cells ("T" cells), there is a third type of cells that are typically Purkinje like cells, presenting in the atrium so those are termed (atrial Purkinje like cells or Purkinje-like conduction cells) that appeared very few in number, may be only one or two cells inside the SAN head but appeared numerous in the SAN arms (Figure 5). These cells were observed as round, larger in size than the two types of modified cardiac myocytes and also larger than the ordinary cardiac myocytes. Its cytoplasm is pale as it contains a very fewer myofibrils and rich in glycogen (Figure 4) in the nodal head and (Figure 5) in the nodal arms. These cells have single, central, large nuclei and sometimes are binucleated with prominent nucleoli (Figure $5 c$ and $5 d$ ). The nuclear chromatin is dispersed and in most cases tended to be condensed peripherally. Moreover, these cells are reacted positively with PAS (Figure 4e).

All three types of these cells has less myofibrils than the working cardiac myocytes, therefore, they are distinctively paler than the working cardiac myocytes (Figures $2 a$ and $2 b$ ). These all three types of SAN cells are separated from each other by a considerable amount of loose connective tissue that is mainly composed of fine collagen (Figure 3b) and reticular fibers (Figure 3f), having some fibroblasts. Moreover, this intercellular connective tissue is reacted positively with PAS (Figure 3d and 3e).

The SAN arms (Figure $6 \mathrm{a}$ and $6 \mathrm{~b}$ ) are mainly consisted of cells that having the same characters of the atrial Purkinje like cells but with small size (Figure $6 \mathrm{c}$ and $6 \mathrm{~d}$ ). These cells beside P- cells and T- cells have large processes that extend from the node to different sites and directions throughout the atrial wall (Figure $6 \mathrm{a}$ and $6 \mathrm{~b}$ ).Very close to the SAN, there is large, elongated medium sized artery as the central artery of the SAN (Figure 6a). The collagen (Figure 2b), and reticular fibers (Figure $2 c$ ) are regularly organized around the central artery. The terminal crest is covered externally by a single layer of simple squamous mesothelial cells that are supported by a subepicardial connective tissue

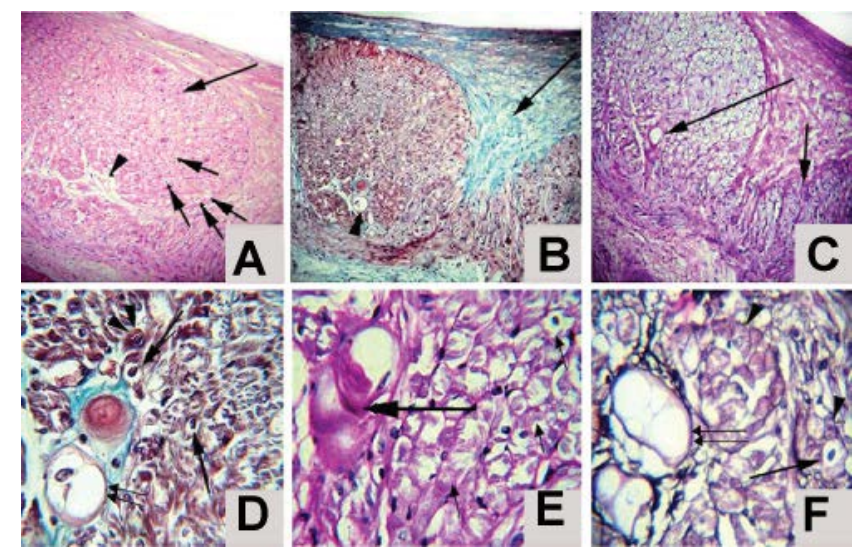

Figure 4: (A) A photomicrograph of the SAN showing the second lobe of the SAN head having; P. cells (short arrow) and T. cells (long arrow) and the atrial purkinje like cell (arrow head) Stain: H\&E Obj.x10 : Oc.x10. (B) showing the collagen fiber (long arrow), and the atrial purkinje like cell (arrow head) Stain: Green Masson's Trichrome Obj.x10: Oc.x10. (C) showing the SAN arm (short arrow), and the atrial purkinje like cell (long arrow) Stain: PAS Obj.x10: Oc.x10. (D) showing the P. cells (single arrow) and T. cells (arrow head) and the atrial purkinje like cell double arrows) Stain: Green Masson's Trichrome Obj.x40: Oc.x10. (E) showing the strongly PAS positive reaction of the atrial purkinje like cell (long arrow) Stain: PAS Obj.x40: Oc.x10. (F) showing P. cells (single arrow) and T. cells (arrow head) and the atrial purkinje like cell (double arrow) Stain: Jone's Methenamine Silver stain Obj.x40: Oc.x10. 


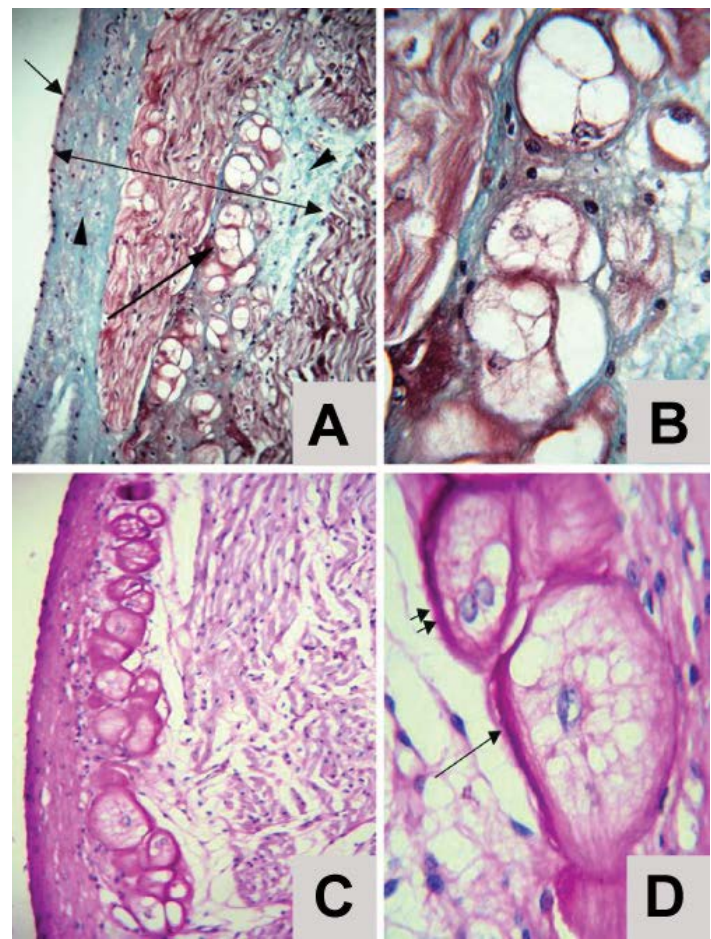

Figure 5: (A) A photomicrograph of the terminal crest epicardium showing the subepicardium (double head arrow) the mesothelium (short arrow), the collagen fibers (arrow heads) and the atrial purkinje like cell (long arrow) Stain: Green Masson's Trichrome Obj.x10 : Oc.x10. (B) High magnification of (Fig. 24) showing the atrial purkinje like cell Stain: Green Masson's Trichrome Obj.x40: Oc.x10. (C) showing the strongly PAS positive reaction of the subepicardium CT. and the atrial purkinje like cell Stain: PAS Obj.x10: Oc.x10. (D) High magnification of (Fig. 26) showing the atrial purkinje like cell; uninucleated (arrow) and binucleated (double arrow) Stain: PAS Obj.x40: Oc.x10.

(Figure $5 c$ and $6 e$ ).

\section{Discussion}

SAN lies beneath the epicardium, at terminal sulcus, near the junction between the superior vena cava, lateral wall of the right atrium and the right auricle. It is embedded without sharp demarcation in the musculature which continues from the atrium onto the superior vena cava. This location of SAN is similar as that in human [12], dogs [13], cattle [14], horses [15], camels [16], domestic cats [17], goats [5] and camel [18]. While in rabbits, it is located at the junction of the mid portion of sinus intercavarum and terminal crest [19]. In turkey, the sino-atrial node lied in the region between the orifices of the right cranial vena cava and of the caudal vena cava and beneath the atrial epicardium [20]. Moreover, the location of sino-atrial node in fowl is completely similar to that described in turkey [21].

SAN is one of the impulses conducting system of the heart and also, is considered a small mass of modified cardiac muscle termed the "pacemaker" for the heart as it has the basic ability to initiate and generate excitation. This investigation is in parallelism with [22] in human who confirmed that the sinus node generates the electrical impulse, which spreads rapidly over both atria, causing them to contract simultaneously, and also goes hand in hand with [23] in mammals who

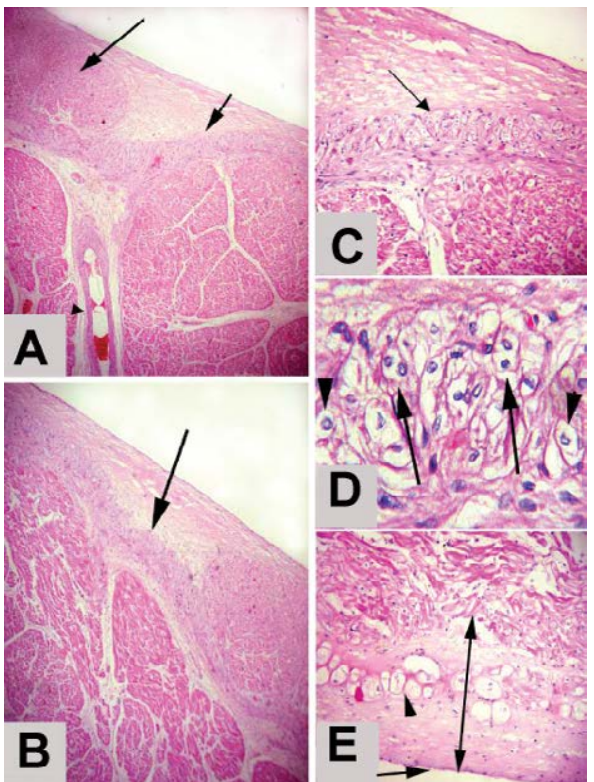

Figure 6: (A) A photomicrograph of the terminal crest epicardium showing the sinu-atrial node head (long arrow), arm (short arrow) and BVs (arrow head) Stain: H\& E Obj. $\mathrm{x} 4$ : Oc.x10. (B) showing the long and extended arm (arrow) Stain: H\& E Obj.x4 : Oc.x10. (C) showing the SAN arm cells; atrial purkinje like cells (arrow) Stain: H\& E Obj.x10 Oc.x10. (D) High magnification of (Fig. 21) showing the atrial purkinje like cells; uninucleated (arrow heads) and binucleated (arrows) Stain: H\& E Obj.x40: Oc.x10. (E) A photomicrograph of the terminal crest epicardium showing the subepicardium (double head arrow), atrial purkinje like cell (arrow head) and the mesothelium (arrow) Stain: H\& E Obj.x10:Oc.x10.

clarified that the main function of the sinus node is to provide the electrical impulse responsible for normal cardiac rhythm.

Histologically, SAN is located in the subepicardial layer of the terminal crest and identifiable as a mass of specialized and modified myocardial cells. This location of sino-atrial node is very close and similar to the finding that described by $[16,18]$ in camel, [5] in goat, [24] in human and [23] in mammals.

The sinus node is appeared elongated in shape, bent oblong and relatively cone shape. This finding is similar as that described in camels, it was elongated in shape and bent oblong [16]. Meanwhile, in humans it resembled and extended like a snail with its shell [12]. In dogs, the shape was oblong or spindle- like and its variations were even greater than in humans [13]. In horses, tapering cranial and caudle crura of the node encircled the lateral half of the junction of the cranial vena cava with the right atrium [15]. In rabbits, the shape was oblong with its long axis parallel to the terminal crest [19]. In cats, the shape was almost triangular [17]. In guinea pig, its shape is like a trapezoid with curved sides [25]. In turkey, it was conical to a limited degree. Its cranial end was near the right auricle and caudal end was near the myocardium of the atrial wall. The cranial end was narrower than caudal end [20].

The histological structure of the SAN simulated to the general structure of the glands as, it is formed of two parts; the stroma and the parenchyma. The stroma is consisted of a fibrous connective tissue 
Citation: Ghonimi W, Balah A, Bareedy MH, Soliman MMS, Sharaf A, et al. (2015) Sinu-atrial Node of Mature Dromedary Camel Heart (Camelus dromedarius) with special Emphasis on the Atrial Purkinje like Cardiomyocytes. J Cytol Histol 6: 319. doi:10.4172/2157-7099.1000319

capsule which is mainly consisted of dense collagenous fibers that is completely investing the SAN from all sides. Moreover, some reticular fibers are also present in the capsule beside the collagen fibers. This investigation indicates that the sinus node is typically similar the gland in its structure so, it is called the sinus gland or the sinu-atrial gland. And also, these investigations are typically similar to those described by Ghonimi, et al. [18] in camel and Nabipour [23] in mammals, who added that the sino-atrial node is surrounded with dense collagen frame. This study revealed that there are some cells within the node were observed round or ovoid, has a relatively large perinuclear clear zone, has few myofibrils in the cytoplasm with single, central, large nucleus in the cross sections. These cells are the perinuclear clear zone cells or (P-cells). This result is generally in agreement with Ghazi and Tadjalli, Ghonimi et al. [16,18] in camel, Nabipour et al. [5] in goat, and Nabipour [23] in mammals. The current work revealed that there are another cell type within the node appeared round or ovoid but smaller in size than the perinuclear clear zone cells and working myocardiocytes, without perinuclear clear zone, has more myofibrils than the perinuclear clear zone cells with single, central, large nucleus with distinct nucleoli in the cross sections. These cells are the transitional or (T-cells), so simulating to those described by Ghazi and Tadjalli, Ghonimi et al. $[16,18]$ in camel.P-cells are appearing smaller in size than the working cardiomyocytes but are bigger than the (T-cells), so coinciding with the result of Ghonimi et al. [18] in camel.The two cell types are arranged longitudinally into fibers and make contacts between themselves, but separated about working cardiomyocytes by dense collagenous fibrous CT capsule. These cells have less myofibrils than the working myocardiocytes, therefore, they are distinctively paler than the working myocardiocytes. Moreover, these two types of cells are considered the principle cells of the node parenchyma. This result is in coincidence with [16] in camel, Nabipour et al. [5] in goat, and Nabipour [23] in mammals.

The two types of cells are weakly reacted with PAS showing the presence of few amount of glycogen in the cells cytoplasm. This result is goes hand in hand with Nabipour et al. [5] in goat and Ghonimi et al. [18] in camel Beside the perinuclear clear zone cells and transitional cells, there is a third type of cells that appeared very few in number, may be one or two cells only in the SAN. These cells were observed round, larger in size than the two types of modified myocardiocytes and also larger than the ordinary cardiac myocytes. Its cytoplasm is pale as it contains a very fewer myofibrils. It has single, central, large nucleus and sometimes binucleated with prominent nucleoli. The nuclear chromatin is dispersed and in most cases tended to be condensed peripherally. Furthermore, these cells are reacted positively with PAS showing the presence of large amount of glycogen in its cytoplasm. Moreover, these cells having the same character of the purkinje cells but with small size. This result is not in coincidence with Ghonimi et al. [16] in camel, Nabipour et al. [5] in goat, and Nabipour [23] in mammals, who reported that there were only two principle kinds of nodal cells; perinuclear clear zone cells (P-cells) and transitional cells (T-cells). Meanwhile, this investigation is completely in coincidence with Ghonimi et al. [18] in camel.All types of SAN cells are laterally separated from each other by a considerable amount of loose connective tissue that is mainly composed of fine collagen and reticular fibers, having some fibroblasts. This result is partially in agreement with Ghonimi et al. [16] in camel, Nabipour et al. [5] in goat, and Nabipour [23] in mammals who described that, in the interstitial between the P-cells and T-cells, there are loose connective tissue of collagen fibers with some fibroblast and arterioles. Moreover, this investigation is completely in parallelism with Ghonimi et al. [18] in camel.Furthermore, the intercellular connective tissue is a very thin and few in between the three types of the nodal cells where, these cells are very large in number and also much closed to each other, appearing overcrowded and forming some sort of network-like structure. This result is indicating the hyper activity of the sinus node.

\section{Conclusion}

We were concluded that the SAN anatomically lies beneath the epicardium, at the cranial end of the terminal sulcus, near the junction between the superior vena cava to the lateral wall of the right atrium and the right auricle. Histologically, SAN is located in the subepicardial layer of the terminal crest and appeared elongated in shape and bent oblong. SAN appears strongly similar to the general structure of the glands as, it is formed of stroma and parenchyma. So, it is named sinus gland. Moreover, it is formed of nodal head and arms that giving the octopus like-appearance. The parenchyma is consisted of three different types of specialized and modified cardiac myocytes; the perinuclear clear zone cells ("P" cells), the transitional cells ("T" cells) and the atrial Purkinje like cells

\section{References}

1. Anderson RH, Yanni J, Boyett MR, Chandler NJ, Dobrzynski H (2009) The anatomy of the cardiac conduction system. Clin Anat 22: 99-113.

2. Sánchez-Quintana D, Yen Ho S (2003) [Anatomy of cardiac nodes and atrioventricular specialized conduction system]. Rev Esp Cardiol 56: 10851092.

3. Getty R (1975) Sisson and Grossman's. The anatomy of the domestic animals (5th edn), W.B. Saunders Company. Philadelphia, London, Toronto.

4. Nickel R, Schummer A, Seiferle E (1984) Lehrbuch der Anatomie der Haustiere Vol. II, (2nd edn), Verlag Paul Parey. Parey, Berlin, Hamburg.

5. Nabipour A, Khanzadi S, Moradi GH (2000) Anatomy of the sinu-atrial node in the heart of goat (Capra hircus). J Fac of Vet Med Tehran Univ, 55: 93-96.

6. Cormack DH (2001) Essential histology (2nd edn) Baltimore, Maryland, USA.

7. Dellmann HD, Eurell J (1998) Text book of veterinary histology, (5th edn) Williams \& Wilkins, Baltimore, Maryland.

8. Fawcett DW, Jensh RP (1997) Concise histology. London \& New York.

9. Bancroft JD, Gamble M (2001) Theory and practice of histological techniques (5th edn), Churchill livingstone.

10. Sheehan D, Hrapchak B (1980) Theory and practice of histotechnology. (2nd edn), Battelle Press, Ohio.

11. Crookham J, Dapson R (1991) Hazardous chemicals in the histopathology laboratory. (2nd edn), Anatech.

12. James TN (1961) Anatomy Of The Human Sinus Node. Anat Rec 141: 109-139.

13. James TN (1962) Anatomy Of The Sinus Node Of The Dog. Anat Rec 143 251-265.

14. James TN (1965) Anatomy of the sinus node, av node and os cordis of the beef heart. Anat Rec 153: 361-371.

15. Bishop SP, Cole CR (1967) Morphology of the specialized conducting tissue in the atria of the equine heart. Anat Rec 158: 401-415.

16. Ghazi SR, Tadjalli M (1996) Anatomy of the sinus node of camels (Camelus dromedarius). Anat Histol Embryol 25: 37-41.

17. Ghazi SR, Nabipour A, Tadjalli M (1998) Anatomy of the sinus node of domestic cats (Felis catus). J Appl. Anim Res, 14: 57-64

18. Ghonimi W, Balah A, Bareedy MH, Abuel-atta AA (2015) Some histological, immunohistochemical and ultrastructural studies on the heart wall of the mature one-humped camel (Camelus dromedarius). Ph. D. thesis. Faculty of veterinary medicine, Zagazig university. Cairo. Egypt.

19. James TN (1967) Anatomy of the cardiac conduction system in the rabbit. Circ Res 20: 638-648.

20. Nabipour A, Tahoonghi M (2008) Histological study on the sinu-atrial node of 
Citation: Ghonimi W, Balah A, Bareedy MH, Soliman MMS, Sharaf A, et al. (2015) Sinu-atrial Node of Mature Dromedary Camel Heart (Camelus dromedarius) with special Emphasis on the Atrial Purkinje like Cardiomyocytes. J Cytol Histol 6: 319. doi:10.4172/2157-7099.1000319

Page 6 of 6

turkey. World Journal of Zoology. 3: 8-12.

21. Kim Y, Yasuda M (1979) The cardiac conducting system of the fowl. Anat Histol Embryol 8: 138-150.

22. Bakker ML, Moorman AF, Christoffels VM (2010) The atrioventricular node: origin development, and genetic program. Trends Cardiovasc Med 20: 164-171.
23. Nabipour A (2012) Comparative histological structure of the sinus node in mammals. Turk J Vet Anim Sci 36: 463-469.

24. Ho SY, Anderson RH, Sánchez-Quintana D (2002) Atrial structure and fibres: morphologic bases of atrial conduction. Cardiovasc Res 54: 325-336.

25. Nabipou A (2004) Anatomy and histology of the sinu-atrial node in the heart of guinea pig (Cavia Percellus). J Appl Anim Res 25: 41-43.
Citation: Ghonimi W, Balah A, Bareedy MH, Soliman MMS, Sharaf A, et al. (2015) Sinu-atrial Node of Mature Dromedary Camel Heart (Camelus dromedarius) with special Emphasis on the Atrial Purkinje like Cardiomyocytes. J Cytol Histol 6: 319. doi:10.4172/2157-7099.1000319
Submit your next manuscript and get advantages of OMICS Group submissions

\section{Unique features:}

User friendly/feasible website-translation of your paper to 50 world's leading languages

Audio Version of published paper

Digital articles to share and explore

Special features:

400 Open Access Journals

30,000 editorial team

21 days rapid review process

Quality and quick editorial, review and publication processing

Indexing at PubMed (partial), Scopus, EBSCO, Index Copernicus and Google Scholar etc

Sharing Option: Social Networking Enabled

Authors, Reviewers and Editors rewarded with online Scientific Credits

Better discount for your subsequent articles

Submit your manuscript at: http://www.omicsonline.org/submission 